Scarlet and Black 



\title{
Scarlet and Black
}

\author{
Volume 1
}

\section{Slavery and Dispossession in Rutgers History}

\author{
EDITED BY MARISA J. FUENTES AND \\ DEBORAH GRAY WHITE
}

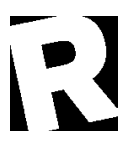

RUTGERS UNIVERSITY PRESS

NEW BRUNSWICK, CAMDEN, AND NEWARK, NEW JERSEY, AND LONDON 


\section{RUTTGERS \\ 250}

PCN 2016955389

ISBN 978-0-8135-9152-0 (pbk.)

ISBN 978-0-8135-9210-7 (ePub)

ISBN 978-0-8135-9211-4 (Mobi)

ISBN 978-0-8135-9212-1 (Web PDF)

This collection copyright (c) 2016 by Rutgers, The State University

Individual chapters copyright ( 2016 in the names of their authors

All rights reserved

No part of this book may be reproduced or utilized in any form or by any means, electronic or mechanical, or by any information storage and retrieval system, without written permission from the publisher. Please contact Rutgers University Press, 106 Somerset Street, New Brunswick, NJ 08901. The only exception to this prohibition is "fair use" as defined by U.S. copyright law.

The paper used in this publication meets the requirements of the American National Standard for Information Sciences-Permanence of Paper for Printed Library Materials, ANSI Z39.48-1992.

www.rutgersuniversitypress.org

Manufactured in the United States of America 